\begin{tabular}{|c|c|c|c|c|c|c|}
\hline \multirow{2}{*}{\multicolumn{2}{|c|}{$\begin{array}{l}\text { Disease Activity } \\
\text { Assessment }\end{array}$}} & \multicolumn{4}{|c|}{ RAPID-3 } & \multirow[b]{2}{*}{ Kappa } \\
\hline & & $\begin{array}{c}\text { Remission } \\
\leq 3\end{array}$ & $\begin{array}{l}\text { LOWDA } \\
>3-\leq 6\end{array}$ & $\begin{array}{l}\text { ModDA } \\
>6-\leq 12\end{array}$ & $\begin{array}{c}\text { HighDA } \\
>12\end{array}$ & \\
\hline \multicolumn{7}{|c|}{ DAPSA } \\
\hline 疎 & $\begin{array}{l}\text { Remission } \\
\text { LowDA } \\
\text { ModDA } \\
\text { HighDA }\end{array}$ & $\begin{array}{c}29(20.9) \\
15(10.8) \\
6(4.3) \\
4(2.9)\end{array}$ & $\begin{array}{l}3(2.2) \\
11(7.9) \\
8(5.8) \\
4(2.9)\end{array}$ & $\begin{array}{c}1(0.7) \\
6(4.3) \\
17(12.2) \\
12(8.6)\end{array}$ & $\begin{array}{c}0 \\
1(0.7) \\
4(2.9) \\
18(12.9)\end{array}$ & $\begin{array}{l}0.388^{\prime \prime} \\
0.572^{b}\end{array}$ \\
\hline $\begin{array}{l}\frac{8}{8} \\
\frac{\pi}{a}\end{array}$ & $\begin{array}{l}\text { Remission } \\
\text { LowDA } \\
\text { ModDA } \\
\text { HighDA }\end{array}$ & $\begin{array}{l}4(2.8) \\
5(3.4) \\
1(0.7) \\
1(0.7)\end{array}$ & $\begin{array}{c}0 \\
3(2.1) \\
7(4.8) \\
4(2.8)\end{array}$ & $\begin{array}{c}0 \\
5(3.4) \\
16(11) \\
29(20)\end{array}$ & $\begin{array}{c}0 \\
1(0.7) \\
9(6.2) \\
60(41.4)\end{array}$ & $\begin{array}{l}0.284^{2} \\
0.484^{b}\end{array}$ \\
\hline \multicolumn{7}{|c|}{ Minimal Disease Activity } \\
\hline 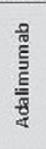 & $\begin{array}{c}\text { MDA } \\
\text { Yes } \\
\text { No } \\
\text { VLDA } \\
\text { Yes } \\
\text { No }\end{array}$ & $\begin{array}{c}45(32.1) \\
9(6.4) \\
11(15.3) \\
17(23.6)\end{array}$ & $\begin{array}{c}5(3.6) \\
21(15) \\
0 \\
12(16.7)\end{array}$ & $\begin{array}{c}1(0.7) \\
36(25.7) \\
0 \\
17(23.6)\end{array}$ & $\begin{array}{c}0 \\
23\{16.4\} \\
0 \\
15\{20.8\}\end{array}$ & $0.574^{c}$ \\
\hline $\begin{array}{l}\frac{8}{0} \\
\frac{\pi}{2}\end{array}$ & $\begin{array}{c}\text { MDA } \\
\text { Yes } \\
\text { No } \\
\text { VLDA } \\
\text { Yes } \\
\text { No }\end{array}$ & $\begin{array}{l}7(4.8) \\
4(2.8) \\
\\
1(1.4) \\
7(10.1)\end{array}$ & $\begin{array}{c}0 \\
14(9.7) \\
0 \\
0 \\
5(7.2)\end{array}$ & $\begin{array}{c}0 \\
50(34.5) \\
0 \\
17(24.6)\end{array}$ & $\begin{array}{c}0 \\
70(48.3) \\
0 \\
39(56.5)\end{array}$ & $0.119^{c}$ \\
\hline $\begin{array}{l}\text { All val } \\
\text { 'Kapp } \\
\text { DAPSA } \\
\text { "Kapp } \\
\text { activit } \\
\text { 'Kapp } \\
\text { activit } \\
\text { activit } \\
\text { DAPA } \\
\text { Minim } \\
\text { enthes } \\
\text { RAPID } \\
\text { minim } \\
\text { activit }\end{array}$ & $\begin{array}{l}\text { are } n(\%) \text {, unle } \\
\text { reem ent betw } \\
\text { reement betw } \\
\text { teg ories of the } \\
\text { reement betw } \\
\text { teg ories of the } \\
\text { sease activitys } \\
\text { lise ase activity } \\
\text { points } \leq 1 \\
\text { routine assessn } \\
\text { lise ase activity, } \\
\text { LDA, very low }\end{array}$ & $\begin{array}{l}\text { wise indicatec } \\
\text { numbers of } p= \\
\text { numbers of } p a \\
\text { and the DAP } \\
\text { umbers of } p a \\
\text { and achiever } \\
\text { mission, } \leq 4 ; \text {;o } \\
T J C \leq 1 \text {, SJC } \leq 1 \\
\text { atient index } \\
\text { low dise ase a } \\
\text { tivity. }\end{array}$ & $\begin{array}{l}\text { ts across the } \\
\text { ts in the ren } \\
\text { ts in the ren } \\
t \text { (yes/no) of } \\
\text { A, S14; Mod } \\
\text { SI S1; patier } \\
\text { DAPSA, dis } \\
\text { ty, ModDA, }\end{array}$ & $\begin{array}{l}\text { ease activity } \\
\text { on + LowDA } \\
\text { on + LowDA } \\
\text { MDA) or } 7 \text { of } \\
\leq 28 \text {; HighDA } \\
\text { in } \leq 15 \text {; patie } \\
\text { activity inde }\end{array}$ & $\begin{array}{l}\text { ModDA + Hi } \\
\text { ModDA + Hit } \\
\text { LDA) criteria } \\
8 . \\
\text { lobal } \leq 20 ; H A \\
\text { psoriatic art }\end{array}$ & $\begin{array}{l}\text { - } 3 \text { and the } \\
\text { ise ase } \\
\text { isease } \\
\text { imal disease } \\
0.5 \text {; tender } \\
\text { MDA, } \\
\text { dise ase }\end{array}$ \\
\hline
\end{tabular}

design, data collection, analysis, interpretation, and abstract writing, review, and approval. Medical writing: Ben Wolfe of AbbVie.

Disclosure of Interest: P. Mease Grant/research support from: AbbVie, Amgen, Bristol Myers, Celgene, Genentech, Janssen, Lilly, Merck, Novartis, Pfizer, Sun Pharma, and UCB, Consultant for: AbbVie, Amgen, Bristol Myers, Celgene, Genentech, Janssen, Lilly, Merck, Novartis, Pfizer, Sun Pharma, and UCB, Speakers bureau: AbbVie, Amgen, Bristol Myers, Celgene, Genentech, Janssen, Lilly, Merck, Novartis, Pfizer, Sun Pharma, and UCB, S. Chen Shareholder of: AbbVie, Inc., Employee of: AbbVie, Inc., F. Ganz Shareholder of: AbbVie, Inc., Employee of: AbbVie, Inc., W. Tillett Grant/research support from: AbbVie, Celgene, Novartis, Pfizer, and UCB, Consultant for: AbbVie, Celgene, Novartis, Pfizer, and UCB, Speakers bureau: AbbVie, Celgene, Novartis, Pfizer, and UCB DOI: 10.1136/annrheumdis-2017-eular.1952

\section{FRI0511 SECUKINUMAB DEMONSTRATES CONSISTENT SAFETY OVER LONG-TERM EXPOSURE IN PATIENTS WITH PSORIATIC ARTHRITIS AND MODERATE-TO-SEVERE PLAQUE PSORIASIS: UPDATED POOLED SAFETY ANALYSES}

P.J. Mease ${ }^{1}$, I.B. Mclnnes ${ }^{2}$, K. Reich ${ }^{3}$, P. Nash ${ }^{4}$, M. Andersson ${ }^{5}$, K. Abrams ${ }^{6}$, L. Pricorp ${ }^{6}$, T. Fox ${ }^{5} .{ }^{1}$ Swedish Medical Center and University of Washington, Seattle, United States; ${ }^{2}$ University of Glasgow, Glasgow, United Kingdom; ${ }^{3}$ Dermatologikum Hamburg and Georg-August-University Göttingen, Hamburg, Germany; ${ }^{4}$ University of Queensland, St Lucia, Australia; ${ }^{5}$ Novartis Pharma AG, Basel, Switzerland; ${ }^{6}$ Novartis Pharmaceuticals Corp., East Hanover, United States

Background: Pooled safety data from secukinumab psoriasis ( $\mathrm{PsO}$ ) and psoriatic arthritis (PsA) clinical trial programs after $\sim 1$ year of exposure have been reported. ${ }^{1,2}$

Objectives: To report updated longer-term secukinumab exposure safety data from PsO and PsA studies (data cut-off: 25 June 2016).

Methods: The PsO data pool consisted of 9 Phase III studies in moderate-tosevere plaque PsO and PsA pool consisted of 3 Phase III studies in active PsA. Secukinumab doses differed in the studies and included intravenous (up to 10 $\mathrm{mg} / \mathrm{kg}$ ) or subcutaneous (s.c.; 75-300 mg) loading, followed by s.c. maintenance dosing (300, 150 or $75 \mathrm{mg}$ ). Placebo patients were re-randomised to secukinumab at 12-24 weeks depending on study design. Only data for approved secukinumab 300 and $150 \mathrm{mg}$ doses were included in analysis. Exposure adjusted incident rates (EAIR) were used to adjust for differences in exposure.

Results: In both PsO and PsA, the most frequently reported adverse events (AEs) with secukinumab were non-serious infections of the upper respiratory tract, headache and arthralgia (Table). The EAIRs of AEs of special interest with secukinumab including Crohn's disease, Candida infections, serious infections, inflammatory bowel disease, major adverse cardiac events and neutropenia (reported in the Table) were similar in both PSO and PsA indications, and comparable to those reported previously. ${ }^{1,2}$ No cases of tuberculosis (new onset or reactivation) were reported.
Table 1. Summary of pooled safety of secukinumab in PSO and PsA

\begin{tabular}{lcc}
\hline & $\begin{array}{c}\text { PSO } \\
\text { Any secukinumab } \\
\mathrm{N}=3893\end{array}$ & $\begin{array}{c}\text { PsA } \\
\text { Any secukinumab } \\
\mathrm{N}=1128\end{array}$ \\
\hline Total exposure, patient-years ) & 7769.0 & 1907.0 \\
Min-max exposure (days) & $1-1526$ & $16-1464$ \\
Death, $\mathrm{n}(\%)$ & $7(0.2)$ & $4(0.4)$ \\
AE's by EAIR: AE per 100 Pt-years $(95 \% \mathrm{Cl})$ & & \\
$\quad$ Any AE & $196.9(190.3,203.6)$ & $173.7(162.5,185.5)$ \\
$\quad$ Any serious AE & $7.2(6.6,7.8)$ & $8.5(7.2,10.0)$ \\
Frequent AEs ${ }^{1}$ & & \\
$\quad$ Nasopharyngitis & $18.2(17.1,19.3)$ & $13.7(12.0,15.7)$ \\
$\quad$ Headache & $6.3(5.7,6.9)$ & $4.8(3.9,5.9)$ \\
$\quad$ Upper respiratory tract infections & $6.2(5.6,6.8)$ & $11.2(9.6,12.9)$ \\
$\quad$ Arthralgia & $5.1(4.6,5.6)$ & $4.3(3.4,5.3)$ \\
AEs of special interest & & \\
$\quad$ Candida infections & $2.1(1.8,2.4)$ & $2.3(1.6,3.1)$ \\
$\quad$ Serious infections & $1.4(1.2,1.7)$ & $1.8(1.3,2.5)$ \\
Inflammatory Bowel Disease & $0.3(0.2,0.4)$ & $0.5(0.2,0.9)$ \\
Crohn's disease & $0.1(0.0,0.1)$ & 0 \\
Ulcerative colitis & $0.2(0.1,0.3)$ & $0.1(0.0,0.4)$ \\
MACE & $0.3(0.2,0.5)$ & $0.3(0.1,0.6)$ \\
Neutropenia & $0.4(0.3,0.5)$ & $0.7(0.4,1.2)$ \\
\hline
\end{tabular}

${ }^{1}$ Adverse events in the secukinumab group that occurred with an IR $>5.0$ during the entire safety period in either of the spooled groups; AE, adverse event; EAIR, exposure adjusted incidence rate per 100 patient-years; MACE, major adverse cardiac event; N, number of patients in the analysis.

Conclusions: The safety profile of secukinumab was similar for PsO and PsA patients supporting its long-term use in these chronic conditions. Secukinumab long-term exposure safety data is consistent with that previously reported with shorter-term exposure, including being well tolerated, and without any new safety signals identified.

References:

[1] Van de Kerkhof PC, et al. J Am Acad Dermatol 2016;75:83-98.

[2] Mease PJ, et al. Arthritis Rheumatol 2015; 67:A2886.

Disclosure of Interest: P. Mease Grant/research support from: AbbVie, Amgen, Biogen Idec, BMS, Celgene, Crescendo, Janssen, Lilly, Merck, Novartis, Pfizer, and UCB, Consultant for: AbbVie, Amgen, Biogen Idec, BMS, Celgene, Covagen, Crescendo, Janssen, Lilly, Merck, Novartis, Pfizer, UCB, Speakers bureau: AbbVie, Amgen, Biogen Idec, BMS, Crescendo, Janssen, Lilly, Pfizer, and UCB, I. McInnes Grant/research support from: AbbVie, Amgen, BMS, Celgene, Janssen, Lilly, Novartis, Pfizer, and UCB, Consultant for: AbbVie, Amgen, BMS, Celgene, Janssen, Lilly, Novartis, Pfizer, and UCB, Speakers bureau: AbbVie, Amgen, BMS, Celgene, Janssen, Lilly, Novartis, Pfizer, and UCB, K. Reich Grant/research support from: AbbVie, Amgen, Biogen, Boehringer Ingelheim Pharma, Celgene, Centocor, Covagen, Forward Pharma, GlaxoSmithKline, Janssen-Cliag, Leo, Lilly, Medac, Merck Sharp and Dohme Corp., Novartis, Ocean Pharma, Pfizer, Regeneron, Takeda, UCB Pharma, Xenoport, Speakers bureau: AbbVie, Amgen, Biogen, Boehringer Ingelheim Pharma, Celgene, Centocor, Covagen, Forward Pharma, GlaxoSmithKline, Janssen-Cliag, Leo, Lilly, Medac, Merck Sharp and Dohme Corp., Novartis, Ocean Pharma, Pfizer, Regeneron, Takeda, UCB Pharma, Xenoport, P. Nash Grant/research support from: AbbVie, Amgen, BMS, Celgene, Eli Lilly, Hospira, MSD, Pfizer, Janssen, UCB, Novartis, Roche; Consultancy fees: AbbVie, Amgen, BMS, Celgene, Eli Lilly, Hospira, MSD, Pfizer, Janssen, UCB, Novartis, Roche, Speakers bureau: AbbVie, Amgen, BMS, Celgene, Eli Lilly, Hospira, MSD, Pfizer, Janssen, UCB, Novartis, Roche, M. Andersson Employee of: Novartis, K. Abrams Shareholder of: Novartis, Employee of: Novartis, L. Pricorp Shareholder of: Novartis, Employee of: Novartis, T. Fox Shareholder of: Novartis, Employee of: Novartis

DOI: 10.1136/annrheumdis-2017-eular.4991

\section{FRI0512 APREMILAST, AN ORAL PHOSPHODIESTERASE 4 INHIBITOR, IS ASSOCIATED WITH LONG-TERM (156-WEEK) IMPROVEMENTS IN BASDAI IN PSORIATIC ARTHRITIS PATIENTS: POOLED RESULTS FROM 3 PHASE III, RANDOMIZED, CONTROLLED TRIALS}

P.J. Mease ${ }^{1}$, H. Marzo-Ortega ${ }^{2}$, A. Poder ${ }^{3}$, F. Van den Bosch ${ }^{4}$, J. Wollenhaupt ${ }^{5}$, E. Lespessailles ${ }^{6}$, M. Mcllraith ${ }^{7}$, L. Teng ${ }^{7}$, S. Hall ${ }^{8} .{ }^{1}$ Swedish Medical Center and University of Washington School of Medicine, Seattle, United States: ${ }^{2}$ NIHR Leeds Musculoskeletal Biomedical Research Unit, Leeds Teaching Hospitals and University of Leeds, Leeds, United Kingdom; ${ }^{3}$ Clinical Research Centre Ltd, Tartu, Estonia; ${ }^{4}$ UZ Gent, Gent, Belgium; ${ }^{5}$ Schön Klinik Hamburg Eilbek, Hamburg, Germany; ${ }^{6}$ University of Orléans, Orléans, France; ${ }^{7}$ Celgene Corporation, Summit, United States; ${ }^{8}$ Monash University, CabriniHealth, Melbourne, Australia

Background: In PALACE psoriatic arthritis (PSA) studies, the Bath Ankylosing Spondylitis Disease Activity Index score (BASDAl) was used as an exploratory measure in a subset of patients (pts) considered by investigators to have axial involvement, although PSA spondylitis was not confirmed by imaging.

Objectives: Report the impact of apremilast $30 \mathrm{mg}$ BID (APR) treatment on BASDAl over 156 wks using pooled PALACE 1-3 data of pts with active PsA despite prior conventional DMARDs and/or biologics. 
Methods: APR treatment outcomes were evaluated in a subset of pts with baseline (BL) BASDAI $\geq 4$ ("subset") over 156 wks.

Results: BL BASDAI $\geq 4$ was reported for $454 / 1493(30 \%)$ pts. Mean PsA duration was similar between the subset and rest of the PALACE 1-3 population $(n=1039)$; mean BL psoriasis body surface area (BSA) and percentage of pts with $\mathrm{BSA} \geq 3 \%$ were slightly higher. The subset had higher mean BL values vs the rest of PALACE $1-3$ pts for C-reactive protein (1.12 vs 0.93 ), pain VAS (63.6 vs $53.8 \mathrm{~mm}$ ), pt's global assessment of disease activity (62.2 vs $53.5 \mathrm{~mm}$ ), and physician's global assessment of disease activity (PhGA; 59.0 vs $53.0 \mathrm{~mm}$ ) and markedly worse mean HAQ-DI (1.41 vs 1.08), SF-36v2 Physical Functioning (30.6 vs 35.8$)$, and FACIT-F (25.7 vs 31.8$)$ scores. Despite disease activity differences, BL concomitant oral DMARDs were similar in both groups: 1 DMARD in $61.0 \%$ (subset) vs $57.8 \%$ (rest of PALACE 1-3 pts); methotrexate was the most common DMARD. In the subset, $73.6 \%$ had been treated with only oral DMARDs prestudy (44.9\% with only 1 ); $25.1 \%$ had prior biologic use. Mean BL BASDAI in the subset was 6.6 with APR and 6.4 with placebo (PBO). Mean BL BASDAl question 2 score, referring directly to spinal and hip pain, was 6.7. APR resulted in greater mean improvement in BASDAI vs PBO at Wk $16(-1.53$ vs $-0.91 ; P=0.0173)$ and Wk 24 (Table). As early as Wk 16, a 19\% mean decrease in the question 2 score was seen with APR vs an increase with PBO. Other disease measures significantly improved early in treatment, including HAQ-DI, fatigue, PhGA, and mPsARC (Table). Long-term improvement was seen across measures, with mean BASDAI reductions of 2.18 at Wk 52 and 2.19 at Wk 156 (Table) and question 2 reductions of 1.94 and 2.28 , respectively; treatment resulted in a shift toward lower BASDAI across the subset, with a significant proportion reaching BASDAI $<4$.

\begin{tabular}{|c|c|c|c|c|}
\hline \multicolumn{5}{|c|}{ Outcomes at Wk 24, Wk 52, and Wk 156 in Pts With BASDAI $\geq 4$ at BL } \\
\hline & \multicolumn{2}{|c|}{ Wk 24} & Wk 52 & Wk 156 \\
\hline & $\begin{array}{c}\text { APR } \\
n=156\end{array}$ & $\begin{array}{l}\mathrm{PBO} \\
\mathrm{n}=151\end{array}$ & $\begin{array}{c}\text { APR } \\
n=125\end{array}$ & $\begin{array}{c}\text { APR } \\
n=127\end{array}$ \\
\hline BASDAl, mean BL & 6.6 & 6.4 & 6.6 & 6.6 \\
\hline BASDAl, mean change from $\mathrm{BL}$ & $-1.64^{*}$ & -0.74 & -2.18 & -2.19 \\
\hline Swollen joint count, mean change & $-5.5^{*}$ & -2.4 & -8.5 & -10.6 \\
\hline HAQ-DI, mean change & $-0.301^{*}$ & -0.117 & -0.464 & -0.448 \\
\hline SF-36v2 PF, mean change & $4.98^{*}$ & 1.76 & 7.06 & 8.21 \\
\hline Pain VAS, mean change, $\mathrm{mm}$ & $-12.6^{*}$ & -7.9 & -22.1 & -21.9 \\
\hline FACIT-F, mean change & $4.38^{*}$ & 1.29 & 6.77 & 6.31 \\
\hline $\begin{array}{l}\text { Pt's global assessment of disease } \\
\text { activity, mean change (VAS mm) }\end{array}$ & -10.9 & -5.7 & -19.8 & -21.2 \\
\hline PhGA, mean change (VAS mm) & $-22.1^{5}$ & -7.4 & -34.3 & -40.2 \\
\hline Proportion meeting mPsARC, $\%$ & $46.2^{\S}$ & 23.8 & 77.9 & 84.1 \\
\hline
\end{tabular}

The $n$ may vary slightly for the end points at pts randomized at BL in the subset; last-observation-carried-forward methodology and non-respond imputation rule were applied to pts who early escaped at Wk 16 or had missing value at Wk 24 for
continuous data and binary response, respectively. For Wk 52 , the $n$ represents the number of pts continuous data and binary response, respectively. For $W k 52$, the $n$ represents the number of $p$
randomized to APR at BL in the subset, with an outcome measure at Wk 52 . For Wk 156 , the $n$ represents the number of pts who were randomized to APR (at BL. Wk 16, or Wk 24), with an outcom measure at Wk 156

${ }^{*} P<0.05 ; \$ P<0.0001$ vs $P B O$, based on an analysis of covariance model for the change from $B L$, with treatment group, BL DMARD use (yes/no), and study as factors and BL value as the covariate, and the Cochran-Mantel-Haenszel test for binary response, adjusting for BL DMARD use and study. Pt's global assessment of disease activity APR $30 \mathrm{mg}$ BID vs $P B O$ at Wk 24: $P=0.0590$.

BASDAl=Bath Ankylosing Spondylitis Disease Activity Index score; APR=apremilast $30 \mathrm{mg}$ BID $\mathrm{PBO}=$ placebo; $\mathrm{BL}=$ baseline; $\mathrm{HAQ}-\mathrm{DI}=$ Health Assessment Questionnaire-Disability Index score; SF-36v2 $\mathrm{PF}=36$-item Short-Form Health Survey version 2 Physical Functioning domain score; VAS=visual analog scale; FACIT-F=Functional Assessment of Chronic Illness Therapy-Fatigue score; PhGA=physician's global assessment of disease activity; mPsARC=modified Psoriatic Arthritis Response Criteria; DMARD=disease-modifying anti-rheumatic drug.

Conclusions: In this post hoc analysis of pooled data, pts reporting BASDAI $\geq 4$ at $\mathrm{BL}$ appear to experience greater disease burden, including disability, pain, and fatigue; effective treatment strategies may not have been available. APR treatment resulted in long-term improvements in BASDAI and other measures in pts with clinically suspected axial disease.

Disclosure of Interest: P. Mease Grant/research support from: Abbott, Amgen, Biogen Idec, BMS, Celgene Corporation, Genentech, Janssen, Eli Lilly, Novartis, Pfizer, Roche, UCB, Consultant for: Abbott, Amgen, Biogen Idec, BMS, Celgene Corporation, Genentech, Janssen, Eli Lilly, Novartis, Pfizer, Roche, UCB, Speakers bureau: Abbott, Amgen, Biogen Idec, BMS, Genentech, Janssen, Eli Lilly, Pfizer, UCB, H. Marzo-Ortega: None declared, A. Poder: None declared, F. Van den Bosch Consultant for: AbbVie, Celgene Corporation, Merck, Pfizer, UCB, Janssen, J. Wollenhaupt Grant/research support from: Abbott, BMS, MSD, Pfizer, UCB, Consultant for: Abbott, BMS, MSD, Pfizer, UCB, E. Lespessailles Grant/research support from: Amgen, Eli Lilly, Novartis, Servier, Speakers bureau: Amgen, Eli Lilly, Novartis, Servier, M. Mcllraith Employee of: Celgene Corporation, L. Teng Employee of: Celgene Corporation, S. Hall Consultant for: Boehringer Ingelheim, MSD, Roche, Schering-Plough, Servier, Wyeth, Paid instructor for: Amgen, AstraZeneca, Boehringer Ingelheim, Centocor, GSK, MSD, Pfizer, Sanofi Aventis, Sanofi Pasteur, Schering-Plough, Serono, Wyeth, Speakers bureau: Boehringer Ingelheim, GSK, MSD, Pfizer, Roche, Sanofi Aventis, Schering-Plough, Wyeth DOI: 10.1136/annrheumdis-2017-eular.3299

\section{FRI0513 LONG-TERM (156 WEEKS) IMPROVEMENTS IN PHYSICAL FUNCTION OF DMARD-NAÏVE AND DMARD/BIOLOGIC-EXPERIENCED PSORIATIC ARTHRITIS PATIENTS TREATED WITH APREMILAST: DATA FROM A LARGE DATABASE OF 4 PHASE III CLINICAL TRIALS}

P.J. Mease $^{1}$, A. Wells ${ }^{2}$, J. Wollenhaupt ${ }^{3}$, S. Hall ${ }^{4}$, F. Van den Bosch ${ }^{5}$, E. Lespessailles ${ }^{6}$, M. Mcllraith ${ }^{7}$, D. Nguyen ${ }^{7}$, L. Teng ${ }^{7}$, C.J. Edwards ${ }^{8}$. ${ }^{1}$ Swedish Medical Center and University of Washington School of Medicine, Seattle; ${ }^{2}$ Rheumatology and Immunotherapy Center, Franklin, United States; ${ }^{3}$ Schön Klinik Hamburg Eilbek, Hamburg, Germany; ${ }^{4}$ Monash University, CabriniHealth, Melbourne, Australia; ${ }^{5}$ UZ Gent, Gent, Belgium; ${ }^{6}$ University of Orléans, Orléans, France, ${ }^{7}$ Celgene Corporation, Summit, United States;

${ }^{8}$ University Hospital Southampton, Southampton, United Kingdom

Background: Improving and preserving patient (pt) physical function is an important goal for psoriatic arthritis (PsA)

Objectives: To evaluate apremilast's (APR) effects on physical function/functional status for up to $3 \mathrm{yrs}$ in DMARD/biologic-experienced (PALACE 1-3 [PAL1-3] pooled data) and DMARD-naive (PALACE 4 [PAL4]) pts with active PsA.

Methods: Pts were randomized (1:1:1) to placebo (PBO), APR $30 \mathrm{mg}$ BID (APR30), or $20 \mathrm{mg}$ BID (APR20) at baseline (BL). The primary endpoint was at Wk16; a long-term extension is ongoing. A detailed study design has been previously presented. Assessed were mean change from BL HAQ-DI scores and proportions of pts reaching HAQ-DI MCID and reaching scores $<1.0$ (below clinically significant disability), $\leq 0.5$ (minimal disability), and $\leq 0.25$ (general population). Wk16 data were analyzed by LOCF. Wk156 data are as observed. Mean change and MCID outcomes are for all pts receiving APR30 at any time during the study; disability level data are for pts randomized to APR30 at BL. Results: PAL1-3 (biologic/DMARD-experienced) and PAL4 (DMARD-naïve) pts had similar BL SJC/TJC and DAS-28 (CRP), indicating active PSA. PAL1-3 pts had longer mean duration of PSA and psoriasis, higher PASI scores, and greater corticosteroid use at BL. Despite differences, BL physical disability was clinically significant in both populations (mean HAQ-DI, PAL1-3: 1.2; PAL4: 1.1). Marked disability at $B L$ was seen in some pts randomized to APR30, with HAQ-DI scores up to 2.63-2.88. More PAL1-3 vs PAL4 APR30 pts had BL HAQ-DI >1.0 (60\% vs $54 \%$ ), >1.5 (marked difficulty/need for assistive devices, $31 \%$ vs $21 \%$ ), and $>1.75$ (major disability, $19 \%$ vs $10 \%$ ), highlighting need for early, effective treatment (tx). Few APR30 pts had BL scores $\leq 0.5$ (18-22\%) or $\leq 0.25(10-14 \%)$. At Wk16, physical function significantly improved with APR30 vs PBO (mean HAQ-DI change, PAL1-3: -0.23 vs -0.08 ; PAL4: -0.21 vs 0.03 ; both $P<0.0001$ ) and more APR30 vs PBO pts reached HAQ-DI MCID $>0.30$ and $>0.35$. As early as Wk16, overall disability levels also shifted; more APR30 vs PBO pts achieved HAQ-DI $\leq 1.0$ (PAL1-3: $56 \%$ vs $48 \%$; PAL4: $60 \%$ vs $52 \%$ ). At Wk156, marked achievement of HAQ-DI $\leq 1.0, \leq 0.5$, and $\leq 0.25$ was observed in both populations (Table). LOCF analyses confirmed Wk156 results.

\begin{tabular}{|c|c|c|}
\hline \multicolumn{3}{|c|}{ Pts Achieving Improvement in Physical Function by HAQ-DI Level at Wk156* } \\
\hline \multirow[b]{2}{*}{$\begin{array}{l}\text { Pts Achieving HAQ-DI Disability } \\
\text { Threshold, \% }\end{array}$} & PAL1-3 & PAL4 \\
\hline & $\begin{array}{l}\text { APR30 } \\
n=279 \S\end{array}$ & $\begin{array}{c}\text { APR30 } \\
n=94^{\S}\end{array}$ \\
\hline$\leq 1.0^{1}$ & 62 & 65 \\
\hline$\leq 0.5^{2}$ & 38 & 45 \\
\hline$\leq 0.25$ & 28 & 42 \\
\hline Pts Achieving HAQ-DI MCID Levels, \% & $\begin{array}{l}\text { APR30 } \\
n=413^{\ddagger}\end{array}$ & $\begin{array}{l}\text { APR30 } \\
n=143 \ddagger\end{array}$ \\
\hline$\geq 0.30^{31}$ & 48 & 48 \\
\hline$\geq 0.35^{4 \pi}$ & 48 & 48 \\
\hline \multicolumn{3}{|c|}{ 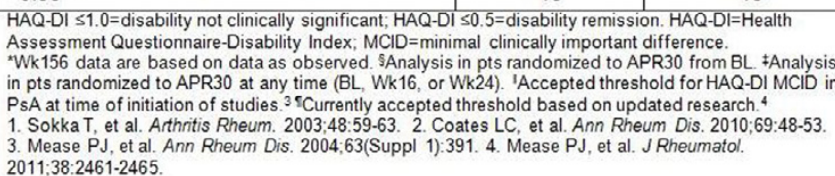 } \\
\hline
\end{tabular}

Conclusions: With APR30 tx, physical disability improved early; functionality was maintained for up to 3 yrs. Most pts achieved HAQ-DI $\leq 1.0$; many attained minimal/mild physical impairment. Over $40 \%$ of pts receiving APR30 earlier in the tx paradigm had functional ability similar to population norms after 3 yrs; shorter disease duration and no prior DMARD/biologics use in this population suggests that earlier APR tx may increase the likelihood of maximal functionality for some pts.

Disclosure of Interest: P. Mease Grant/research support from: Abbott, Amgen, Biogen Idec, BMS, Celgene Corporation, Genentech, Janssen, Eli Lilly, Novartis, Pfizer, Roche, UCB, Consultant for: Abbott, Amgen, Biogen Idec, BMS, Celgene Corporation, Genentech, Janssen, Eli Lilly, Novartis, Pfizer, Roche, UCB, Speakers bureau: Abbott, Amgen, Biogen Idec, BMS, Genentech, Janssen, Eli Lilly, Pfizer, UCB, A. Wells Grant/research support from: Celgene Corporation, J. Wollenhaupt Grant/research support from: Abbott, BMS, MSD, Pfizer, UCB, Consultant for: Abbott, BMS, MSD, Pfizer, UCB, S. Hall Consultant for: Boehringer Ingelheim, MSD, Roche, Schering-Plough, Servier, Wyeth, Paid instructor for: Amgen, AstraZeneca, Boehringer Ingelheim, Centocor, GSK, MSD, Pfizer, Sanofi Aventis, Sanofi Pasteur, Schering-Plough, Serono, Wyeth, Speakers bureau: Boehringer Ingelheim, GSK, MSD, Pfizer, Roche, Sanofi Aventis, Schering-Plough, Wyeth, 